\title{
談話室 $\bullet$
}

\section{名にし負わば……}

\section{産業技術総合研究所＼cjkstart吉澤徳子}

冒頭から恐縮であるが,このタイトルはあまり本文内容と関係 なく，「名前」についてこれから書くにあたり，単に思い出した フレーズである。百人一首にもこれで始まる歌があるが，もし ご存知のうえでロマンチックな内容を想像した方があれば申 し訳ない。

年度初めの人事異動などで環境が変わり, 新しく知り合った 人たちと過ごす日々に, しばらくは緊張感いっぱいの毎日を過ご す方も多いと思う。ところで, 出会えば次には「名前」を知る ことになる。私は人の名前を覚えるのが苦手であるが,たとえ ば最初の会話からなるべく名前を呼びかけるようにすると， それなりに頭に入ってくるものらしい。それでもうっかり失念 してしまうことが多々あり,関連する失敗はいまだに後を絶た ない。

さて, 先ごろ映画化され話題となったミステリー小説「チー ム・バチスタの栄光」(海堂尊・作)を読んだ。大学付属病院 で心臓移植の代替手術であるバチス夕手術の専門のグループ “チーム・バチス夕”が, 成功率 $100 \%$ を誇る実績でその勇名 を轟かせている。ところが, 3 例立て続けに術中死が発生。危 機感を抱いた病院長が, 心臓外科は専門外である講師に内部調 査を依頼する話である。登場人物のキャラクターの明確さ, 会話 劇としてのストーリー展開の上手さに引き达まれ，一気に読んで しまった。中でも私にとり面白かった場面の1つは,この講師 がチーム・バチス夕の構成員に個別に事情聴取を行うところ である。手術中の様子などを一通り尋ねた後, 最後に必ず「個 人的な興味でお伺いするのですが」と前置きして, 相手の名前の 由来を尋ねるのだ。これが結構その人の本質を見抜く, 良い質 問らしく，「そんなこと軽々しく説明できない」と言って話さ ない人や,「所詮こんな名前ですよ」と荥んで話す人, あるいは 「こういう夢が込められているんです」と自信をもって話す人 がある。そこに, 本人が自分とどうやって向き合っているのか という姿勢が垣間見えるということだ。確かに自分の名前は 自分で用いるばかりでなく, 他人の口から発せられ, 最終的に は 1 対 1 で本人とつながるものである。そう考えるとこの講師 の質問は, 相手の自意識を垣間見るでも良い質問なのだろうと いう点で興味深く感じた。

さて, 実社会に目を向けると, 名前の重要性はまた別の意味 をもつ。相手を姓 (ファミリーネーム) で呼ぶ習慣に慣れてい
る日本から, 名 (ファーストネーム) あるいは名をベースにし た愛称で呼ぶ習慣のあるアメリカのような国に行った場合, 気 恥かしさを感じた経験のある人も多いのではないだろうか。 日本の中での話となれば, 旧姓などいわゆる通称名の使用希望 者に対する配慮が男女ともに進められてきている。私の所属 する産総研では旧姓使用を届け出た場合, 給料や健康診断に関 すること以外はほとんど戸籍名を使わずに仕事ができる。身 分証明書にも戸籍名は記載されない。またパスポートは, その名 前の社会的な必要性を証明できる書類（研究者であれば論文 や, 所属機関からの証明書など) を添えて申請すれば, 戸籍名 にカッコ付きで通称名を添えることが可能である。

また法律上の話とは別に, 名前によって自分の仕事が性格付 けられる場面もある。いくつかの分野で, それぞれ異なる立場 で研究活動をしていた知人が，「スタンスの違いを明確にする ために, 論文によってはペンネームを使いたいことがある」と 言うのを聞いたことがある。ここまで来ると作家並みである が, 名前も商売道具の1つであるプロたちにとっては切実な問 題らしい。実際, 私の友人のイラストレーターは, うっかり本 名でデビューしたらそこそこに売れてしまい, この名前で好き 勝手な仕事ができなくなったと贅沢な悩みをこぼしていた。

炭素材料についても「名前」を調べると，そこに込められた 思いが感じ取られて面白い。炭素同素体の,

・グラファイト : ギリシャ語の graphein (書くの意)に由来。 ・ダイヤモンド：ギリシャ語の adamas（征服できない）に由来。 との説は, 昔の人がこれらの結晶（というょりも石・素材であ ろうか) を手にした感覚がそのまま伝わってくるようである。 また近年では, カーボンナノチューブ・ナノファイバー・ナノ ホーンなど形態がそのまま名前となった例がある一方，フラー レンがバックミンスター・フラー氏の設計したドーム建築と似 た形であることに由来することは有名である。これらは形そ のものを裸眼で見るわけにはいかないが, それでも TEM 観察 から, あるいは計算結果から構造モデルを推定したときの興奮が その名前から理解できる。学術的・論理的な正当性があり，し かも想像力を膨らませてくれるような夢のある名前は素敵なも のだ。

最後に多少私事を。私の名前は建礼門院（平清盛の娘）に。 あやかったもので,才色兼備を祈って父が付けてくれたらしい。 しかも今のところ期待をかなり外している。お父さんごめん なさい。頑張ります。ちなみに私には妹があり, 亜紀という。 次女なので 2 番目を意味する「亜」と，母からもらった「紀」。 の組み合わせだそうだ。姉が言うのも何だが, 私と違ってしっ かりもの・癒し系・色白美人である。ただ今, 将来をともにし てくれるお相手を大募集中である。真面目に関心を寄せてい ただける方,ぜひご一報いただきたい。 